\title{
Tindakan Agresivitas Pajak dipandang dari Teori Akuntansi Positif
}

\author{
Dian Sulistyorini Wulandari \\ Universitas Diponegoro, Indonesia \\ diansulistyorini@students.undip.ac.id
}

\begin{abstract}
Taxes are one of the state's largest sources of income. For businesses, taxes are a burden that can reduce profits. The government wants high tax revenues, but businesses want low tax revenues. Therefore, this is a tax avoidance act that seeks to minimize the amount of tax a company pays for violating or being legal. This study aims to determine how tax aggressiveness can be seen from aggressive accounting theory. The tax aggressiveness measure uses the company's ETR. This is the income tax expense divided by the profit before income tax. The sample of this survey consists of manufacturers listed on the Indonesia Stock Exchange (IDX) between 2017 and 2019. Targeted sampling was used to select the samples, and 54 companies obtained samples. The analytical method used is multiple regression analysis. The results of this study show that the Inventory Intensity does not affect tax aggressiveness. Capital Intensity, Fixed Assets Intensity, and Firm Size have a significant positive impact on tax aggressiveness.
\end{abstract}

Keywords: Tax Aggressiveness, Inventory Intensity, Capital Intensity, Fixed Assets Intensity, Firm Size.

\section{PENDAHULUAN}

Pajak merupakan sumber utama penerimaan negara yang digunakan untuk membiayai pengeluaran negara. Hal ini dapat terlihat pada periode 2016-2019, penerimaan pajak mengalami pertumbuhan rata-rata sebesar $6,4 \%$ antara lain dipengaruhi oleh peningkatan kinerja ekonomi dan harga komoditas utama. Pada tahun 2020 penerimaan pajak terkontraksi dampak dari perlambatan ekonomi dan pemberian insentif dampak pandemi Covid-19. Tahun 2021, penerimaan pajak akan melanjutkan dukungan pemulihan ekonomi secara lebih terukur dan diproyeksikan tumbuh positif sejalan dengan prospek membaiknya perekonomian dan dukungan kelanjutan reformasi administrasi pajak. (kemenkeu.go.id, 2021).

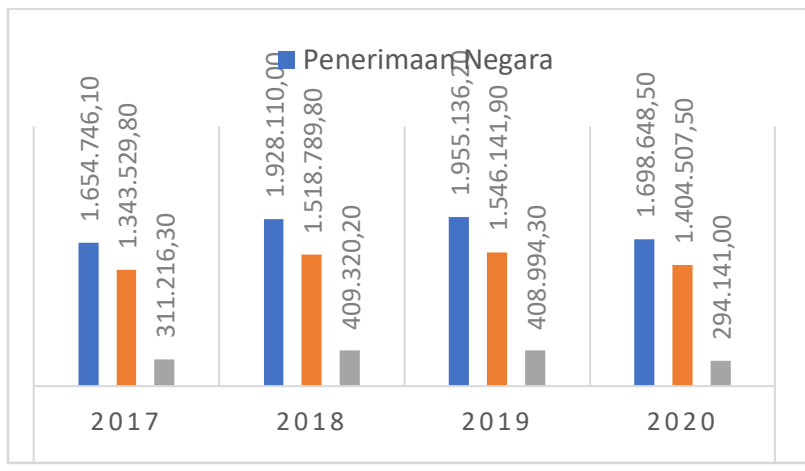

Gambar 1. Proporsi Penerimaan Negara Tahun 2017-2020

Sumber : Badan Pusat Statistik.

Berdasarkan Gambar 1 di atas diketahui Penerimaan Negara selama 4 tahun terakhir, yakni tahun 2017-2020 (dalam triliyun). Pada tahun 2017 total penerimaan negara sebesar Rp.1.654.746,10, penerimaan pajak Rp.1.343.529,80, dan PNBP (Pendapatan Negara Bukan Pajak) Rp.311.216,30. Pada tahun 2018 total penerimaan negara sebesar Rp.1.928.110,00, penerimaan pajak Rp.1.518.789,80, dan PNBP (Pendapatan Negara Bukan Pajak) Rp.409.320,20. Sedangkan tahun 2019 penerimaan negara sebesar Rp.1.955.136,20, penerimaan pajak Rp.1.546.141,90 dan PNBP 
(Pendapatan Negara Bukan Pajak) Rp.408.994,30. Selanjutnya tahun 2020 penerimaan negara sebesar Rp.1.698.648,50, penerimaan pajak Rp.1.404.507,50, dan PNBP (Pendapatan Negaara Bukan Pajak) Rp.294.141,00. Jadi dapat dianalisis, bahwa selama 4 tahun terakhir (tahun 20172020) adalah yang terbesar berasal dari sektor penerimaan pajak, yang notabene dipungut dan menjadi kewajiban masyarakat. Dimana pajak tetap merupakan sumber penerimaan dominan dalam struktur APBN.

Dalam mengukur kinerja penerimaan pajak di suatu negara terdapat banyak cara, salah satunya adalah dengan memakai rasio pajak atau Tax Ratio. Fungsi pajak pada Tax Ratio yaitu untuk memperoleh seberapa besar kira-kira porsi pajak dalam suatu perekonomian negara. Semakin tinggi Tax Ratio maka semakin tinggi juga Anggaran Pendapatan dan Belanja Negara (APBN) hingga dapat digunakan untuk berbagai keperluan negara dari sisi pembangunan ataupun fasilitas Dilihat dari tax ratio Indonesia, tax ratio Indonesia tergolong rendah. Hal ini dikemukakan oleh Sri Mulyani Indrawati (2021), penerimaan negara, khususnya perpajakan pada 2020 mengalami dampak yang luar biasa akibat pandemi Covid-19 dimana tax ratio Indonesia turun di bawah 9 persen. Sejak 2018-2020, kinerja tax ratio atau rasio pajak Indonesia tercatat masih rendah dibandingkan negara-negara Eropa Barat atau ASEAN, seperti Singapura, Malaysia, Thailand, Philipina. Dalam kurun waktu tersebut, rasio pajak Indonesia stagnan di angka 10-12\%. Sementara, Singapura mencatatkan di level 13-14\%.Sedangkan, Malaysia 12-15\%, Philipina 1718\%, Thailand 17-17,5\%, dan tertinggi adalah Eropa Barat yakni 41\% (Ramalan Suparjo, 2021) Penerimaan dari pajak harus terus ditingkatkan dan dioptimalkan agar laju pertumbuhan ekonomi negara dan pelaksanaan pembangunan dapat berjalan dengan baik. Peningkatan penerimaan pajak diupayakan tidak hanya mengandalkan peranan Dirjen Jenderal Pajak saja, tetapi juga partisipasi dan antusias dari wajib pajak sendiri (Friskianti \& Handayani, 2014). Wajib pajak yang taat dalam membayar pajak telah turut serta membantu pemerintah dan negara dalam usaha peningkatan kesejahteraan rakyat dan bangsa Indonesia, serta turut dalam usaha pembangunan negara Indonesia secara umum. Oleh karena itu penting bagi pemerintah untuk mengetahui faktor-faktor yang dapat mempengaruhi besarnya penerimaan pajak sehingga dapat menyusun kebijakan yang tepat dan sesuai dengan ketentuan perpajakan.

Upaya pemerintah untuk melakukan pengoptimalan dalm sektor pajak ini bukan tanpa kendala.. Disisi lain, para pelaku bisnis menggangap pajak sebagai beban investasi. Oleh sebab itu, sudah menjadi hal yang umum apabila perusahaan berusaha untuk menghindari beban pajak. Salah satu tindakan manajemen yang direncanakan untuk menghindari pajak perusahaan yang tinggi dilakukan agresivitas pajak (Wardhani \& Muid, 2017).

Agresivitas pajak disebabkan oleh adanya perbedaan kepentingan antara wajib pajak perusahaan dengan pemerintah. Pemerintah membutuhkan dana pajak untuk membiayai penyelenggaraan kegiatan-kegiatan yang dilakukan oleh pemerintah. Sedangkan perusahaan sebagai wajib pajak memandang pajak sebagai biaya tambahan yang harus dikeluarkan perusahaan. Dengan membayar pajak, akan mengurangi jumlah laba bersih yang akan diterima perusahaan. Oleh sebab itu pemilik perusahaan lebih tertarik untuk memanajemen perusahaan melakukan tindakan pajak agresif (Leksono et al., 2019).

Agresivitas pajak dapat diukur dengan skala Effective Tax Rate (ETR) yang paling umum digunakan dalam beberapa literatur. Rentang nilai ETR yang dapat mengidentifikasi agresivitas pajak atau tidak. Contohnya, ETR yang rendah menunjukkan adanya agresivitas pajak. Beberapa perusahaan-perusahaan menghindari pajak dengan bermacam-macam cara seperti mengurangi penghasilan kena pajak perusahaan atau tetap menjaga laba akuntansi keuangan sehingga memiliki nilai ETR yang lebih rendah (Kuriah \& Asyik, 2016). Dengan demikian, ETR dapat difungsikan untuk mengatur agresivitas pajak.

Tabel 1. Data Agresivitas Pajak Perusahaan Manufaktur

\begin{tabular}{|c|c|c|c|}
\hline Nama Perusahaan & $\mathbf{2 0 1 7}$ & $\mathbf{2 0 1 8}$ & $\mathbf{2 0 1 9}$ \\
\hline PT. Astra Otoparts Tbk & 0,103092 & 0,209807 & 0,330344 \\
\hline PT. Garuda Metalindo Tbk & 0,262015 & 0,265232 & 0,280757 \\
\hline PT. Indo Kordsa Tbk & 0,278887 & 0,284901 & 0,948175 \\
\hline PT. Goodyear Indonesia Tbk & 2,362579 & 0,259458 & 122,1438 \\
\hline
\end{tabular}


Sumber : Data Diolah, 2021

Menurut data tabel agresivitas pajak perusahaan manufaktur, perusahaan PT. Astra Otoparts Tbk setiap tahunya mengalami kenaikan tahun 2017 0,103 tahun 2018 0,209 tahun 2019 0,330. Perusahaan PT. Garuda Metalindo Tbk tahun 2017 0,262 tahun 2018 0,265 tahun 2019 0,280 setiap tahunya mengalami kenaikan. Perusahaan PT. Indo Kordsa Tbk tahun 2017 0,278 tahun 2018 0,284 tahun 2019 0,948 setiap tahun mengalami kenaikan. Perusahaan PT. Goodyear Indonesia Tbk tahun 2017 2,362 tahun 2018 mengalami penurunan 0,259 pada tahun 2019 mengalami kenaikan 122,143.

Penghindaran pajak melalui agresivitas pajak sebagian besar jarang diketahui literatur akademis. Perusahaan pada umumnya seringkali melakukan tindakan agresivitas pajak. Hal tersebut dilakukan perusahaan tersebut agar memikliki resiko deteksi yang lebih rendah agar dapat memberikan perlindungan terhadap perusahaan yeng terhubung denganya agar resiko penghindaran pajaknya bisa lebih rendah. Kemudian perusahaan dapat memiliki informasi lebih baik mengenai perubahan peraturan perpajakan dimasa yang akan datang (Rahayu, 2017).

Positive Accounting Theory sebagai grand teori penelitian ini dikenalkan oleh Watts dan Zimmerman tahun 1986. Teori akuntansi positif memaparkan perilaku manajemen perusahaan pada pembuatan laporan keuangan. Teori akuntansi positif menjelaskan praktik akuntansi dengan aktual yang dilihat melalui sudut pandang manajemen yang dengan sukarela menggunakan prosedur akuntansi serta cara standar peraturan akuntansi berubah dari masa ke masa. Teori ini dilandaskan pada stakeholder, shareholder, fiscus bersifat rasional, serta berupaya memaksimalkan fungsi mereka yang akan berhubungan langsung juga pada kompensasi yang diterima, dan kesejahteraan yang diterima. Penggunaan dari kebiajkan akuntansi tersebut tergantung pada relatif biaya, dan manfaat dari prosedur yang dipilih guna memaksimalkan fungsi mereka (Andhari \& Sukartha, 2017).

Dalam teori akuntansi positif manajer akan mengambil kebijakan yang menguntungkan dan memaksimalkan nilai bisnis perusahaan. Hal tersebut terjadi pada kasus PT. Coca Cola Indonesia pada tahun 2014 memanfaatkan kebijakan iklan untuk melakukan penghindaran pajak. Direktorat Jenderal Pajak (DJP) menemukan pembengkakan pada biaya iklan senilai Rp 566,84 Miliyar akibatnya penghasilan kena pajak berkurang sehingga beban kena pajaknya menjadi kecil (Kompas.com, 2014). Sesuai Peraturan Menteri Keuangan Nomor 2/PKM.03/2010 pasal 2 yaitu besarnya biaya promosi dapat dikurangkan dari penghasilan bruto yang merupakan akumulasi dari biaya pengenalan produk baru, biaya periklanan di media elektronik, media cetak, biaya sponshorship, dan biaya pameran produk. Biaya tersebut dapat menjadi salah satu cara untuk meminimalkan beban pajak yang dibayarkan oleh perusahaan.

Perusahaan yang memiliki persediaan dalam jumlah yang banyak juga dapat mengurangi jumlah pajak yang dibayarkan. Hal ini dikarenakan adanya persediaan menimbulkan beban bagi perusahaan. Berdasarkan PSAK No. 14 tahun 2018 kepemilikan persediaan yang besar menimbulkan biaya tambahan (biaya penjualan, biaya bahan, biaya produksi, biaya administrasi dan umum, biaya tenaga kerja, dan biaya penyimpanan atas adanya persediaan) yang harus dikeluarkan dari biaya persediaan dan diakui sebagai beban dalam periode terjadinya biaya. Adanya persediaan dalam jumlah yang besar tentu akan menyebabkan penurunan laba yang diperoleh perusahaan sehingga dapat mengurangi pajak (Andhari \& Sukartha, 2017). Semakin tinggi tingkat inventory intensity perusahaan maka semakin tinggi tingkat penghindaran pajak (Dwiyanti \& Jati, 2019).

Intensitas modal yang dilakukan perusahaan yang dikaitkan dengan investasi dalam bentuk aset tetap. Kepemilikan aset tetap yang tinggi akan menghasilkan beban penyusutan yang tinggi pula, sehingga laba menjadi turun dan beban pajak perusahaan menjadi turun juga. Jadi dengan tingginya jumlah aset yang dimiliki perusahaan mendorong perusahaan melakukan tindakan agresivitas pajak (Novitasari, 2017). Intensitas aset tetap menandakan rasio tentang intensitas kepemilikan aset tetap suatu perusahaan dibandingkan dengan total aset. Kepemilikan aset tetap yang tinggi akan menghasilkan beban depresiasi atas aset yang besar pula, sehingga laba perusahaan akan berkurang akibat adanya jumlah aset tetap yang besar. Sehingga tingginya jumlah aset yang ada di perusahaan akan meningkatkan agresivitas pajak perusahaan. Intensitas 
aset tetap dapat mempengaruhi beban pajak perusahaan karena adanya beban depresiasi yang melekat pada aset tetap (Adisamartha \& Noviari, 2015).

Tindakan agresivitas pajak menurut Ngadiman \& Puspitasari (2017) disebabkan salah satunya oleh ukuran perusahaan. Dalam penelitian tersebut menemukan bahwa perusahaan dengan skala yang lebih besar akan memiliki aktivitas operasi perusahaan yang lebih banyak dan rumit sehingga terdapat celah-celah untuk dimanfaatkan dalam keputusan tax avoidance. Sedangkan Hanum (2013) menjelaskan bahwa perusahaan yang lebih besar akan membayar pajak yang lebih tinggi, sehingga dapat dikatakan laba yang semakin besar akan menunjukkan tarif efektif pajak yang semakin besar juga. Ukuran perusahan adalah kemampuan perusahaan untuk memperoleh laba, semakin besar laba bersih maka perusahaan dianggap semakin besar (Suyanto, 2012). Besar kecilnya sebuah perusahaan dapat dipengaruhi dari seberapa besar penjualan yang dilakukan oleh perusahaan.

Tetapi tidak semua perusahaan besar akan membayar pajak yang tinggi. Dharma \& Ardiana (2016) menunjukkan perusahaan besar akan lebih mudah melakukan praktik tax avoidance karena perusahaan tersebut memiliki sumber daya yang lebih unggul dibandingkan dengan perusahaan kecil. Sumber daya unggul yang dimiliki perusahaan dapat dimanfaatkan untuk meminimalkan beban pajak yang seharusnya dibayarkan dengan cara memanfaatkan celah-celah peraturan perpajakan yang berlaku. Persepsi tersebut sejalan dengan teori akuntansi positif yang dikemukakan oleh Watts dan Zimmerman (1990) menyatakan bahwa tujuan utama teori akuntansi positif adalah untuk menjelaskan dan memprediksi pilihan standar akuntansi oleh manajemen. Dan sejalan juga dengan teori perilaku terencana yang dikemukakan oleh Ajzen (1991) bahwa wajib pajak memiliki kesadaran untuk melakukan tindakan agresif terhadap pajak yang menyebabkan wajib pajak tersebut akan memiliki niat dan melakukan tindakan agresif terhadap pajak.

\section{Penelitian Terdahulu}

\section{STUDI LITERATUR}

Penelitian yang dilakukan oleh Efrinal dan Afia Hilda Chandra (2020) tentang "Pengaruh Capital Intensity dan Inventory Intensity Terhadap Agresivitas Pajak". Penelitian tersebut diterbitkan oleh AKRUAL Jurnal Akuntan dan Keuangan Vol.2 No.2: Juli-Desember 2020. Jenis data dalam penelitian ini adalah kuantitatif. Hasil dari penelitian ini menyatakan bahwa variabel capital intensity berpengaruh positif signifikan terhadap agresivitas pajak, variabel inventory intensity berpengaruh tidak signifikan terhadap agresivitas pajak.

Penelitian yang dilakukan oleh Dewi Susanti dan Made Dudy Satyawan (2020) tentang "Pengaruh Advertising Intensity, Inventory Intensity dan Sales Growth Terhadap Agresivitas Pajak". Penelitian tersebut diterbitkan oleh AKUNESA: Jurnal Akuntansi Unesa Vol.9 No.1, September 2020. Jenis penelitian yang diterapkan yaitu kuantitatif. Hasil dari penelitian tersebut menyatakan bahwa advertising intensity dan sales growth berpengaruh negatif terhadap agresivitas pajak sedangkan inventory intensity tidak berpengaruh terhadap agresivitas pajak.

Penelitian yang dilakukan oleh Ida Ayu Putu Yuli Muliawati dan I Putu Fery Karyada (2020) tentang "Pengaruh Leverage dan Capital Intensity Terhadap Agresivitas Pajak Dengan Komisaris Independen Sebagai Variabel Pemoderasi (Studi Pada Perusahaan Manufaktur Sector Industry Barang dan Konsumsi Yang Terdaftar di Bursa Efek Indonesia Periode 2016-2018)”. Penelitian tersebut diterbitkan oleh Hita Akuntansi dan Keuangan Universitas Hindu Indonesia Edisi Juli 2020. Jenis data dalam penelitian ini adalah kuantitatif dan kualitatif. Hasil dari penelitian tersebut menyatakan bahwa leverage dan capital intensity berpengaruh positif terhadap agresivitas pajak dan komisaris independen memperlemah pengaruh leverage dan capital intensity terhadap agresivitas pajak.

Penelitian yang dilakukan oleh Marlines Rante Allo, Stanly W. Alexander dan I Gede Suwetja (2021) tentang "Pengaruh Likuiditas Dan Ukuran Perusahaan Terhadap Agresivitas Pajak (Studi Empiris Pada Perusahaan Manufaktur Yang Terdaftar Di BEI Tahun 2016-2018)”. Penelitian ini diterbitkan oleh Jurnal EMBA vol.9 No.1 Januari 2021. Jenis penelitian yang digunakan adalah penelitian kausal dengan pendeketan kuantitatif. Hasil dari penelitian 
menyatakan bahwa secara parsial likuiditas dan ukuran perusahaan berpengaruh signifikan terhadap agresivitas pajak.

\section{Tinjauan Pustaka dan Hipotesis Teori Akuntansi Positif}

Positive Accounting Theory sebagai grand teori penelitian ini dikenalkan oleh Watts dan Zimmerman tahun 1986. Teori akuntansi positif memaparkan perilaku manajemen perusahaan pada pembuatan laporan keuangan. Teori akuntansi positif menjelaskan praktik akuntansi dengan aktual yang dilihat melalui sudut pandang manajemen yang dengan sukarela menggunakan prosedur akuntansi serta cara standar peraturan akuntansi berubah dari masa ke masa. Teori ini dilandaskan pada stakeholder, shareholder, fiscus bersifat rasional, serta berupaya memaksimalkan fungsi mereka yang akan berhubungan langsung juga pada kompensasi yang diterima, dan kesejahteraan yang diterima. Penggunaan dari kebiajkan akuntansi tersebut tergantung pada relatif biaya, dan manfaat dari prosedur yang dipilih guna memaksimalkan fungsi mereka.

Sebagai hasil dari pemikiran akuntansi positif, terdapat tiga hipotesis. Hipotesis rencana bonus. Hipotesis ini menyatakan bahwa para manajer perusahaan dengan rencana bonus memiliki peluang besar untuk memakai metode akuntansi meningkatkan laporan laba periode pada periode berjalan. Landasan pikiran tersebut yakni kegiatan seperti itu kemungkinan akan menaikkan persentase jumlah bonus apabila tidak dilakukan penyesuaian pada metode yang dipilih. Hipotesis ekuitas utang. Hipotesis ekuitas utang menyatakan semakin meningkat utang atau ekuitas perusahaan, yakni sama dengan semakin dekatnya perusahaan dengan batasab-batasan yang ada pada perjanjian utang, serta semakin besar peluang dari pelanggaran perjanjian utang dan kejadian kegagalan teknis, sehingga makin besar kemungkinan manajer memperguanakan pilihan metode akuntansi untuk meningkatkan laba. Hipotesis Biaya Politis. Berpendapat bahwa perusahaan besar dan bukannya perusahaan kecil kemungkinan besar akan memilih akuntansi untuk menurunkan laporan laba.

Pada penelitian ini dari 3 hipotesis teori akuntansi positif, hipotesis biaya politik yang paling tepat menggambarkan penelitian ini. Hal ini dikarenakan ketika kondisi lain cateris paribus maka laba yang cukup tinggi, perusahaan memiliki kecenderungan menurunkan laba saat ini menuju ke masa yang akan datang.

Menurut (Watts, R., and Zimmerman, 1986)teori akuntansi positif adalah teori yang menjelaskan sebuah proses, dengan menggunakan pemahaman, kemampuan dan pengetahuan akuntansi yang sesuai dengan kebijakan akuntansi untuk menghadapi kondisi tertentu dimasa yang akan datang, dengan kata lain yaitu bagaimana teori akuntansi positif memberikan kebebasan kepada pihak manajemen untuk memilih berbagai alternatif dari beberapa kebijakan akuntansi yang ada agar dapat meminimalisir biaya serta meningkatkan nilai perusahaan ataupun sebaliknya guna untuk memperkecil pajak terutang badan yang akan dibayarkan suatu perusahaan. Dalam hal tingkat agresivitas pajak, apabila suatu perusahaan memiliki laba periode berjalan yang tinggi, maka tingkat pajak yang dibayarkan juga akan tinggi. Untuk mengurangi tingkat laba periode berjalan, maka pihak manajemen disuatu perusahaan akan berusaha melakukan pengalokasian laba periode berjalan keperiode yang akan datang (Amalia, 2021)

\section{Pengaruh Intensitas Persediaan Terhadap Agresivitas Pajak}

Tingginya tingkat intensitas persediaan menyebabkan penurunan laba perusahaan dikarenakan timbulnya biaya tambahan atas adanya persediaan. Berdasarkan PSAK No. 14 tahun 2018 biaya tersebut diakui sebagai beban pada periode terjadinya biaya sehingga perusahaan akan membayar pajak yang lebih rendah ketika labanya turun. Kondisi ini, sesuai yang diinginkan perusahaan dimana inventory intensity tinggi akan mampu meminimalkan beban pajaknya dan keuntungan pada periode saat ini dapat digantikan oleh stok persediaan yang dialokasikan diperiode mendatang. Oleh karena itu, perusahaan memilih berinvestasi pada persediaan sebagai penerapan teori akuntansi positif dalam memilih kebijakan yang menguntungkan dengan asumsi perusahaan akan memperoleh manfaat pajak yang rendah dan laba yang lebih tinggi diperiode mendatang. Penelitian Anindyka et al., (2018) mendapatkan hasil intensitas persediaan berpengaruh negatif 
terhadap penghindaran pajak, semakin tinggi intensitas persediaan maka semakin kecil agresivitas pajak dan sebaliknya. Berdasarkan uraian di atas, hipotesis yang dapat dirumuskan sebagai berikut:

H1: Intensitas persediaan berpengaruh negatif terhadap agresivitas pajak

\section{Pengaruh Intensitas Modal Terhadap Agresivitas Pajak}

Intensitas Modal menggambarkan berapa besar kekayaan perusahaan yang diinvestasikan pada bentuk aset tetap. Aset tetap mencakup bangunan, pabrik, peralatan, mesin, property. PSAK 16 (revisi 2015) aset tetap adalah aset berwujud yang dimiliki untuk digunakan dalam produksi atau penyedia barang atau jasa, untuk direntalkan kepada pihak lain, atau untuk tujuan administratif dan diperkirakan untuk digunakan selama lebih dari satu periode. Intensitas Modal yang merupakan investasi perusahaan pada aset tetap merupakan salah satu aset yang digunakan oleh perusahaan untuk berproduksi dan mendapatkan laba. Investasi perusahaan pada aset tetap akan menyebabkan adanya beban depresiasi dari aset tetap yang diinvestasikan. Besarnya beban depresiasi untuk aset tetap diperaturan perpajakan Indonesia beraneka ragam tergantung dari klasifikasi aset tetap tersebut. Teori akuntansi positif yang memberikan pilihan kebijakan akuntansi dan memanfaatkan kebijakan akuntansi yang ada untuk meningkatkan labanya, yang mana dalam investasi pada aset, perusahaan dapat memilih metode depresiasi yang dipandang dapat meningkatkan laba perusahaan (Andhari \& Sukartha, 2017).

Andhari \& Sukartha (2017) menyatakan perusahaan dengan aset tetap yang besar cenderung melakukan perencanaan pajak sehingga Effective Tax Ratio (ETR) sebagai salah satu indikator agresivitas pajaknya rendah. Intensitas Modal sangat berhubungan dengan investasi perusahaan dalam aset tetap menjadikan beban depresiasi aset tetap semakin meningkat. Hal ini akan berimplikasi terhadap laba perusahaan yang semakin menurun, sehingga pajak terutang perusahaan juga akan semakin menurun.

Hal ini berarti Intensitas Modal memiliki pengaruh positif terhadap penghindaran pajak, yang artinya semakin tinggi Intensitas Modal perusahaan maka semakin tinggi penghindaran pajak perusahaan. Berdasarkan uraian diatas dapat ditarik hipotesis sebagai berikut:

$\mathrm{H} 2$ : Intensitas Modal berpengaruh positif terhadap agresivitas pajak.

\section{Pengaruh Intensitas Aset Tetap Terhadap Agresivitas Pajak}

Intensitas aset tetap merupakan rasio yang menandakan intensitas kepemilikan aset tetap suatu perusahaan dibandingkan dengan total aset. Kepemilikan aset tetap yang tinggi akan menghasilkan beban depresiasi atas aset yang besar pula, sehingga laba perusahaan akan berkurang akibat adanya jumlah aset tetap yang besar. Sehingga tingginya jumlah aset yang ada di perusahaan akan meningkatkan agresivitas pajak perusahaan. Intensitas kepemilikan aset tetap dapat mempengaruhi beban pajak perusahaan karena adanya beban depresiasi yang melekat pada aset tetap (Adisamartha \& Noviari, 2015). Berdasarkan uraian diatas dapat ditarik hipotesis sebagai berikut:

H3: Intensitas Aset Tetap berpengaruh positif terhadap agresivitas pajak.

\section{Pengaruh Ukuran Perusahaan Terhadap Agresivitas Pajak}

Perusahaan diklasifikasikan kecil atau besar dari salah satunya dari kecil besarnya total penjualan perusahaan. Tolok ukur yang digunakan untuk memperlihatkan kecil besarnya suatu perusahaan, antara lain total penjualan, jumlah pelanggan tetap dan total aktiva. Semakin besar total penjualan atau aset, maka ukuran suatu perusahaan semakin besar juga (Mulianti, 2010). Untuk menurunkan ETR suatu perusahaan perusahaan berkesempatan cukup besar merencanakan pajak yang baik dengan mempraktikan akuntansi yang efektif (Rodriguez dan Arias, 2012). Penjualan yang dilakukan perusahaan akan memengaruhi banyaknya laba perusahaan. Semakin besar laba yang dimiliki suatu perusahaan akan berdampak semakin besarnya juga pajak yang harus dibayarkan perusahaan tersebut. Sejalan dengan teori akuntansi positif, dalam rangka meyakinkan pemerintah bahwa profit yang dimiliki perusahaan tidak terlalu besar perusahaan akan mengadopsi kebijakan akuntansi income-decreasing (pendapatan menurun). Berdasarkan uraian diatas dapat ditarik hipotesis sebagai berikut: 
H4: Ukuran perusahaan berpengaruh positif terhadap agresivitas pajak

\section{METODE}

Jenis Penelitian dan Gambaran dari Populasi (Obyek) Penelitian

Jenis penelitian ini menggunakan metode pendekatan kuantitatif, yaitu penelitian yang lebih fokus pada data numerik yang diolah menggunakan metode statistika. Jenis data yang digunakan adalah data sekunder, dimana jenis data berupa arsip laporan tahunan (annual report) dan informasi lain yang berkaitan dengan penelitian. Desain penelitian ini ditekankan pada pengaruh intensitas persediaan, intensitas modal, intensitas aset tetap dan ukuran perusahaan terhadap agresivitas pajak pada perusahaan manufaktur yang terdaftar di Bursa Efek Indonesia tahun 20172019.

\section{Teknik Pengambilan Sampel}

Sampel penelitian ini menggunakan metode purposive sampling dimana pengambilan sampel menggunakan kriteria tertentu. Daftar perusahaan yang menjadi sampel penelitian diambil dari www.edusaham.com dan www.sahamok.com dan laporan keuangan perusahaan diambil dari www.idx.com. Adapun kriteria sample sebagai berikut: (1) Laporan keuangan perusahaan manufaktur yang terdaftar di Bursa Efek Indonesia tahun 2017-2019. (2) Perusahaan manufaktur yang melaporkan laporan keuangannya tahun 2017, 2018, dan 2019. (3) Perusahaan yang melaporkan keuangannya menggunakan satuan rupiah.

\section{Teknik Pengumpulan Data}

Jenis data yang digunakan adalah data sekunder dimana jenis data berupa arsip laporan tahunan (annual report) dan informasi lain yang berkaitan dengan penelitian. Desain penelitian ini ditekankan pada pengaruh intensitas persediaan, intensitas modal, intensitas aset tetap dan ukuran perusahaan terhadap agresivitas pajak pada perusahaan manufaktur yang terdaftar di Bursa Efek Indonesia tahun 2017-2019. Penelitian ini dilakukan dengan mengambil data di Bursa Efek Indonesia (BEI) melalui situs web www.idx.co.id.

Adapun data yang diperlukan dalam laporan tahunan perusahaan manufaktur yaitu : (1) Laporan posisi keuangan; (2) Laporan laba rugi. Data yang diperoleh kemudian dicatat dan dihitung menggunakan aplikasi microsoft excel. Setelah dihitung, kemudian data dianalisis mengunakan program Stastiscal Package ForSocial Scince (SPSS).

\section{Variabel dan Definisi Operasional Variabel Agresivitas pajak}

Agresivitas pajak diukur menggunakan Effective Tax Rate (ETR), dihitung dari jumlah beban pajak penghasilan di bagi dengan total laba sebelum pajak penghasilan. Agresivitas pajak diukur dengan menggunakan Effective Tax Rate (ETR) seperti halnya penelitian yang dilakukan (Lestari et al., 2019) menyatakan bahwa ETR merupakan salah satu pengukur agresivitas pajak. Rumus ETR adalah:

\section{Intensitas Persediaan}

$$
\mathrm{ETR}=\frac{\text { Beban pajak penghasilan }}{\text { Laba sebelum pajak }}
$$

Intensitas Persediaan menandakan besarnya perputaran persediaan yang terjadi selama periode berjalan. Intensitas Persediaan diperoleh dengan membandingkan total persediaan dengan jumlah total aset (Andhari \& Sukartha, 2017). Intensitas persediaan (IP) menggunakan rumus sebagai berikut:

$$
\mathrm{IP}=\frac{\text { Total persediaan }}{\text { Total aset }}
$$

\section{Intensitas Modal}


Intensitas modal menggambarkan seberapa besar aset perusahaan yang diinvestasikan dalam bentuk aset tetap. Dalam penelitian ini intensitas modal diproksikan menggunakan rasio intensitas aset tetap. Intensitas aset tetap adalah seberapa besar proporsi aset tetap perusahaan dalam total aset yang dimiliki perusahaan (Maulidah \& Prastiwi, 2019). Intensitas modal (IM) menggunakan rumus sebagai berikut:

$$
\mathrm{IM}=\frac{\text { Aset tetap bersih }}{\text { Total aset }}
$$

\section{Intensitas Aset Tetap}

Intensitas aset tetap menunjukkan proporsi aset tetap di dalam perusahaan dibandingkan dengan total aset yang dimiliki. Intensitas Aset Tetap diperoleh dengan membandingkan total aset tetap dan total aset. Menurut (Indradi, 2018) intensitas aset tetap (IAT) dapat diukur dengan rumus sebagai berikut:

$$
\text { IAT }=\frac{\text { Aset tetap }}{\text { Total aset }}
$$

\section{Ukuran Perusahaan}

Ukuran perusahaan merupakan salah satu karakteristik perusahaan yang merupakan variabel penduga dan banyak digunakan untuk menjelaskan variasi pengungkapan dalam laporan tahunan perusahaan. Ukuran perusahaan menggambarkan seberapa besar aset yang dimiliki perusahaan. Menurut (Ayem \& Setyadi, 2019) ukuran perusahaan (size) dapat diukur dengan natural logaritma total aset dengan rumus sebagai berikut:

$$
\text { Size }=\operatorname{Ln}(\text { total aset })
$$

\section{Statistik Deskriptif}

\section{HASIL}

Tabel hasil analisis deskriptif dalam penelitian ini adalah sebagai berikut :

Tabel 2

Hasil Analisis Statistik Deskriptif

\begin{tabular}{ccccccc}
\hline & N & Minimum & Maximum & Mean & Std. Deviation \\
\hline IP & 109 & 1,45 & 44,78 & 20,0559 & 9,23381 \\
IM & 109 & 2,36 & 74,45 & 35,6902 & 17,96004 \\
IAT & 109 & 1,78 & 120,77 & 59,5258 & 25,98603 \\
UP & 109 & 10,45 & 30,03 & 22,9934 & 5,43025 \\
ETR & 109 & 13,49 & 39,35 & 25,1411 & 4,48354 \\
Valid N (listwise) & 109 & & & & \\
\hline
\end{tabular}

Sumber : Data Diolah, 2021

Dari hasil data di atas dapat dijelaskan sebagai berikut, Intensitas Persediaan rata-rata selama tiga tahun adalah 20,0559 dengan standar deviasi 9,23381, nilai minimun 1,45 dan nilai maksimumnya 44,78. Intensitas Modal rata-rata selama tiga tahun adalah 35,6902 dengan standar deviasi 17,96004, nilai minimun 2,36 dan nilai maksimumnya 74,45. Intensitas Aset Tetap ratarata selama tiga tahun adalah 59,5258 dengan standar deviasi 25,98603, nilai minimun 1,78 dan nilai maksimumnya 120,77. Ukuran Perusahaan rata-rata selama tiga tahun adalah 22,9934 dengan standar deviasi 5,48354, nilai minimun 10,45 dan nilai maksimumnya 30,35. Sedangkan Agresivitas Pajak sebagai variabel dependen memiliki nilai rata-rata selama tiga tahun adalah 25,1411 dengan standar deviasi 4,48354, nilai minimun 13,49 dan nilai maksimum 39,35.

\section{Hasil Uji Asumsi Klasik}

Uji Normalitas

Dalam penelitian ini uji normalitas diuji menggunakan Kolmogorov Smirnov, dan juga 
Owner: Riset \& Jurnal Akuntansi

e-ISSN : 2548-9224 | p-ISSN : 2548-7507

Volume 6 Nomor 1, Januari 2022

DOI : https://doi.org/10.33395/owner.v6i1.631

dilihat dari penyebaran data (titik) pada normal P-P Plot of regression Standarized Residual. Berikut ini merupakan hasil dari uji normalitas :

\section{Tabel 3. Hasil Uji Kolmogorof-Smirnov}

\begin{tabular}{|llr}
\hline \multicolumn{1}{c}{} & \multicolumn{2}{c}{$\begin{array}{c}\text { Unstandardized } \\
\text { Residual }\end{array}$} \\
\hline N & Mean & 162 \\
Normal & Std. & 0 \\
Parameters ${ }^{\text {a,b }}$ & Deviation & 27,47164449 \\
& Absolute & 0,301 \\
Most Extreme & Positive & 0,301 \\
Differences & Negative & $-0,171$ \\
Test Statistic & & 0,301 \\
Asymp. Sig. (2-tailed) &, $000^{\mathrm{c}}$ \\
\hline
\end{tabular}

a. Test distribution is Normal.

b. Calculated from data.

Sumber : Data Diolah, 2021

Dari data tabel diperoleh nilai asymp sig (2-tailed) sebesar 0,000 memiliki nilai lebih kecil dari 0,05 . Hal ini dapat disimpulkan bahwa data belum berdistribusi normal, karena belum memenuhi syarat nilai asymp sig lebih besar dari $\alpha$. Agar data berdistribusi normal maka dilakukan transformasi data dengan membuang beberapa data outlier sehingga diperoleh data normal dengan nilai asymp sig sebesar 0,126 seperti tabel berikut :

Tabel 4. Hasil Uji Kolmogorof-Smirnov (Setelah membuang data outlier)

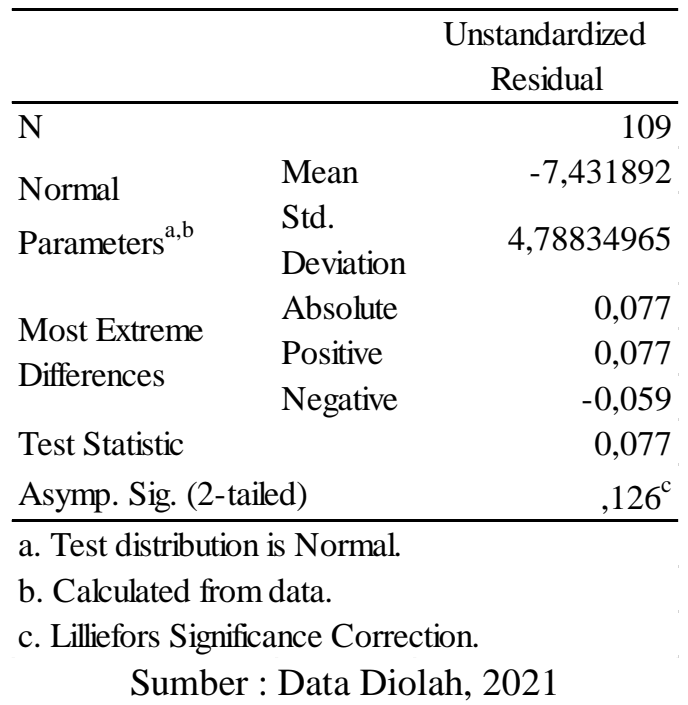




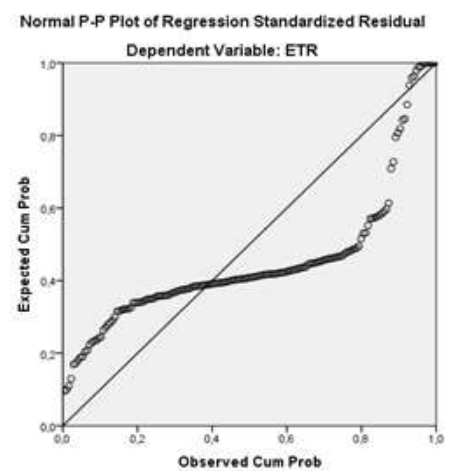

\section{Gambar 2.Grafik Normal P-P Plot of Regression}

Sumber : Data Diolah, 2021

Berdasarkan gambar diatas, terlihat titik menjauh dari garis diagonal dan tidak mengikuti arah garis diagonal. Maka dapat disimpulkan bahwa model regresi linier berganda tidak terdistribusi dengan normal. Salah satu cara agar data dapat terdistribusi dengan normal adalah dengan melakukan membuang data outlier ke bentuk lainnya.

Untuk mengolah nilai residual agar berdistribusi normal, maka penulis melakukan membuang data outlier data dilakukan pada variabel-variabel yang tidak terdistribusi secara normal. Setelah itu dilakukan pengujian ulang atas data berdasarkan asumsi normalitas. Hasil uji normalitas setelah dilakukan membuang data outlier data dapat diihat pada gambar berikut :

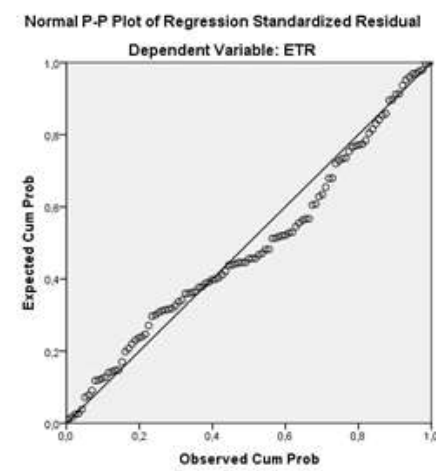

\section{Gambar 3. Grafik Normal P-P Plot of Regression (Setelah membuang data outlier) \\ Sumber : Data Diolah, 2021}

Hasil grafik normal P-P Plot menunjukan bahwa titik-titik menyebar di sekitar garis diagoanal dan mengikuti arah garis diagonal, maka dapat disimpulkan bahwa data penelitian mempunyai distribusi yang normal. Sehingga model ini layak dipakai untuk analisis selanjutnya. Didukung dengan hasil uji Kolmogrov-Smirnov pada gambar 3.

\section{Uji Multikolinieritas}

Uji multikolinearitas bertujuan untuk menguji apakah model regresi ditemukan adanya korelasi antar variabel bebas (Independen). Deteksi multikolinieritas pada suatu model dapat dilihat dimana nilai variance Inflation Faktor (VIF) tidak lebih dari 10 dan nilai tolerance tidak kurang dari 0,1. Maka model tersebut dapat dikatakan terbebas dari multikolinieritas. Berikut ini adalah hasil Uji Multikolonieritas : 


\begin{tabular}{cccc}
\hline \multicolumn{2}{l}{ Model } & \multicolumn{2}{c}{ Collinearity Statistics } \\
& & Tolerance & VIF \\
\hline \multicolumn{4}{c}{ (Constant } \\
& IP & .888 & 1.126 \\
1 & IM & .496 & 1.017 \\
& IAT & .525 & 1.905 \\
& UP & 0,961 & 1,04 \\
\hline \multicolumn{3}{l}{ Sumber : Data Diolah, 2021 }
\end{tabular}

Uji multikolinearitas yang terdapat pada Tabel 5 menunjukkan model regresi yang dipakai untuk variabel- variabel independen penelitian tidak terdapat masalah multikolinearitas. Model tersebut terbebas dari masalah multikolinearitas karena semua variabel menunjukkan nilai Tolerance tidak kurang dari 0,1 dan mempunyai nilai VIF yang tidak lebih dari 10.

\section{Uji heteroskedastisitas}

Uji heteroskedastisitas bertujuan menguji apakah dalam model regresi terjadi ketidaksamaan varian dari residual satu pengamatan ke pengamatan yang lain. Untuk mendeteksi ada atau tidaknya heteroskedastisitas dapat dilakukan grafik scatterplot berikut ini :

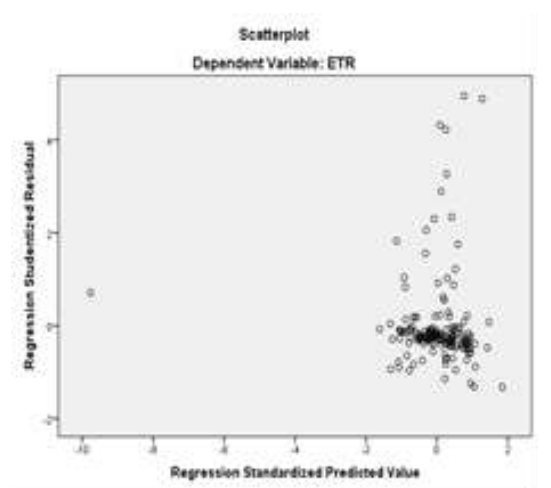

Gambar 4. Scatterplot

Sumber : Data Diolah, 2021

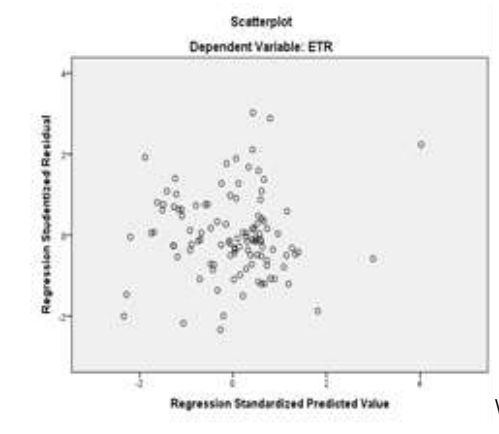

Gambar 5. Scatterplot

(Setelah membuang data outlier)

Sumber : Data Diolah, 2021

Hasil Scatterplot pada gambar 5 tersebut dapat diketahui bahwa tidak ada pola yang jelas. Titiktitik menyebar secara acak di atas dan di bawah angka 0 pada sumbu Y, maka disimpulkan bahwa tidak terjadi Heteroskedastisitas.

\section{Uji Autokorelasi}


Uji autokorelasi dilakukan dengan tujuan untuk menguji apakah dalam suatu model regresi linier terdapat adanya korelasi antara kesalahan penganggu pada periode t-1 atau tahun sebelumnya. Model regresi yang baik terbebas dari autokorelasi. Uji Autokorelasi ini dapat dilihat dengan menggunakan tabel Durbin-Watson (D-W).

Tabel 6. Hasil Uji Autokorelasi Model Summary ${ }^{\mathrm{b}}$

\begin{tabular}{|l|c|r|r|r|r|}
\hline $\begin{array}{l}\text { Mod } \\
\text { el }\end{array}$ & $\mathrm{R}$ & $\begin{array}{c}\mathrm{R} \\
\text { Square }\end{array}$ & $\begin{array}{c}\text { Adjuste } \\
\mathrm{d} \mathrm{R}\end{array}$ & $\begin{array}{c}\text { Std. } \\
\text { Square } \\
\text { the } \\
\text { Estimate }\end{array}$ & $\begin{array}{c}\text { Durbin- } \\
\text { Watson }\end{array}$ \\
\hline 1 &, $312^{\mathrm{a}}$ &, 098 &, 063 & 4,34044 & 1,687 \\
\hline
\end{tabular}

a. Predictors: (Constant), UP, IAT, IP, IM

b. Dependent Variable: ETR

Sumber : Data diolah, 2021

Untuk melihat terjadinya autokorelasi atau tidak dapat dilihat melalui pengujian Durbin-Watson (DW). Oleh karena itu, berdasarkan table diatas diketahui nilai Durbin-Watson sebesar 1.687 dengan jumlah variable independen $4(\mathrm{k}=4)$ dan jumlah sampel $\mathrm{n}=109$ data. diketahui nilai $\mathrm{du}=$ 1,7644 dan nilai $\mathrm{dl}=1,6125$. Sehingga berdasarkan dasar pengambilan keputusan $\mathrm{du}<\mathrm{d}<4-\mathrm{du}$ yaitu 1,7644 (dU) < 1,687 (DW) < 2,2636 (4-dU). Dengan demikian, dapat disimpulkan bahwa model regresi yang dihasilkan dari penelitian ini terbebas dari autokorelasi.

\section{Regresi Linier Berganda}

Analisis regresi berganda digunakan untuk mengukur pengaruh antara variabel independen terhadap vaiabel dependen yaitu intensitas persediaan, intensitas modal, intensitas aset tetap dan ukuran perusahaan terhadap agresivitas pajak. Hasil analisis regresi berganda dapat dilihat pada tabel dibawah ini:

Tabel 7. Hasil Uji Regresi Linier Berganda

\begin{tabular}{|c|c|c|c|c|c|}
\hline \multirow[b]{2}{*}{ Model } & \multicolumn{2}{|c|}{ Unstandardized Coefficients } & \multirow{2}{*}{$\begin{array}{c}\text { Standardized Coefficients } \\
\text { Beta }\end{array}$} & \multirow[b]{2}{*}{$\mathrm{T}$} & \multirow[b]{2}{*}{ Sig. } \\
\hline & B & Std. Error & & & \\
\hline 1 (Constant) & 28,993 & 2,134 & & 13,588 & , 000 \\
\hline IP & ,040 &, 048 & ,08 & 819 & 075 \\
\hline IM & ,062 & ,035 &, 24 & 1,786 & 037 \\
\hline IAT & ,070 & ,023 & 40 & 2,994 & 003 \\
\hline UP & ,118 & ,079 & 14 & 1,485 &, 040 \\
\hline
\end{tabular}

Dari tabel diatas dapat disusun model persamaan regresi linier berganda berdasarkan kolom B. Model persamaan regresi linier berganda hasil penelitian adalah sebagai berikut :

$$
\mathrm{Y}=28,993+0,040 \mathrm{X} 1+0,062 \mathrm{X} 2+0,070 \mathrm{X} 3+0,118 \mathrm{X} 4+\mathrm{e}
$$

\section{Uji Hipotesis}

Berdasarkan uji $\mathrm{t}$ variabel intensitas persediaan diperoleh hasil dengan nilai signifikan 0,075 lebih besar dari 0,05. Hasil penelitian ini dapat disimpulkan bahwa intensitas persediaan tidak berpengaruh terhadap agresivitas pajak, semakin tinggi intensitas persediaan tidak menyebabkan semakin rendah agresivitas pajak, ini berarti H1 ditolak.

Berdasarkan uji $\mathrm{t}$ variabel intensitas modal diperoleh hasil dengan nilai signifikan 0,037 lebih kecil dari 0,05. Hasil penelitian ini dapat disimpulkan bahwa intensitas modal berpengaruh terhadap agresivitas pajak, semakin tinggi intensitas modal menyebabkan semakin tinggi agresivitas pajak, ini berarti $\mathrm{H} 2$ diterima.

Berdasarkan uji t variabel intensitas aset tetap diperoleh hasil dengan nilai signifikan 0,003 lebih kecil dari 0,05. Hasil penelitian ini dapat disimpulkan bahwa intensitas aset tetap berpengaruh 
positif terhadap agresivitas pajak. Hasil penelitian ini dapat disimpulkan bahwa intensitas asset tetap berpengaruh terhadap agresivitas pajak, semakin tinggi intensitas asset tetap menyebabkan semakin naik agresivitas pajak, ini berarti $\mathrm{H} 3$ diterima.

Berdasarkan uji t variabel ukuran perusahaan diperoleh hasil dengan nilai signifikan 0,040 lebih besar dari 0,05. Hasil penelitian ini dapat disimpulkan bahwa ukuran perusahaan berpengaruh terhadap agresivitas pajak, semakin tinggi ukuran perusahaan menyebabkan semakin tinggi agresivitas pajak, ini berarti $\mathrm{H} 4$ diterima.

\section{PEMBAHASAN}

\section{Pengaruh Intensitas Persediaan Terhadap Agresivitas Pajak}

Hasil uji tersebut menunjukkan bahwa inventory intensity tidak berpengaruh terhadap agresivitas pajak. Dimana investasi perusahaan dalam bentuk persediaan sedikit atau banyak bukan merupakan faktor dalam menentukan besar kecilnya pajak yang dibayarkan oleh perusahaan (Tanoto \& Soepriyanto, 2013). Perusahaan biasanya lebih tertarik berinvestasi dalam bentuk aset tetap dimana terdapat beban penyusutan atau depresiasi yang dapat dikurangkan (Darmadi, 2013). Memperbanyak persediaan tidak mendukung teori akuntansi positif. Pemilihan kebijakan tersebut tidak menguntungkan perusahaan dimana menyimpan terlalu lama persediaan akan menyebabkan penurunan nilai dalam akuntansi disebut impairment asset yang diatur di PSAK 48 tentang penurunan nilai. Undang-undang perpajakan tidak memberikan intensif pajak untuk perusahaan dengan kepemilikan persediaan dalam jumlah yang besar (Romadhina, 2017). Ketentuan perpajakan terkait kerugian akibat penurunan harga dari persediaan yang belum terjual tidak boleh dibiayakan dan wajib pajak tidak diperkenankan memperhitungkan penyisihan depresiasi persediaan. Hal tersebut tidak termasuk kategori cadangan yang dapat dikurangkan menurut Peraturan Menteri Keuangan Nomor 219/PMK.011/2012 sehingga ketika menentukan jumlah penghasilan kena pajak dalam penghitungan perpajakan persediaan tetap dihitung senilai harga perolehan yang dicatat tanpa penurunan nilai.

Hasil penelitian ini konsisten dengan penelitian yang dilakukan oleh (Susanti \& Setyawan, 2020) yang menyimpulkan intensitas persediaan tidak berpengaruh terhadap agresivitas pajak.

\section{Pengaruh Intensitas Modal Terhadap Agresivitas Pajak}

Intensitas modal merupakan aktivitas yang dilakukan perusahaan yang dikaitkan dengan investasi dalam bentuk asep tetap. Semakin besar jumlah asset tetap yang dimiliki oleh perusahaan maka akan semakin besar pula beban depresiasi perusahaan. Oleh karena itu, laba sebelum pajak yang dihasilkan perusahaan pun akan kecil dan pajak yang dikeluarkan perusahaan pun akan kecil pula (Lestari, Pratomo, \& Asalam, 2019).

Dalam hal ini dinyatakan bahwa intensitas modal berpengaruh terhadap agresivitas pajak. Intensitas modal menunjukkan efisiensi penggunaan aktiva untuk menghasilkan penjualan. Dimana dalam memperoleh aktiva perusahaan, dana yang dikeluarkan perusahaan tidak dimasukkan kedalam biaya, melainkan dimasukkan kedalam aktiva (Novitasari, Ratnawawati, \& Silfi, 2017). Oleh karena itu, perusahaan dengan tingkat intensitas modal yang tinggi tidak menyebabkan semakin turun agresivitas pajak.

Perusahaan lebih memilih berinvestasi pada aset sehingga timbul beban depresiasi yang tinggi, dan dari beban tersebut akan mengurangi laba perusahaan sehingga dapat berpengaruh kewajiban perpajakan perusahaan. Hasil hipotesis ini mendukung teori akuntansi positif khususnya hipotesis biaya politik, yang mana pada kondisi cateris paribus, perusahaan cenderung untuk menurunkan labanya saat ini menuju ke masa yang akan datang, yang dicerminkan dengan peningkatan beban depresiasi, sehingga kewajiban perpajakannya dapat berkurang.

Hasil penelitian ini konsisten dengan yang dilakukan oleh (Windaswari \& Merkusiwati, 2018) yang menyimpulkan intensitas modal berpengaruh positif terhadap agresivitas pajak.

\section{Pengaruh Intensitas Aset Tetap Terhadap Agresivitas Pajak}

Intensitas aset tetap merupakan proporsi dimana dalam aset tetap terdapat pos bagi perusahaan untuk menambahkan beban yaitu beban penyusutan yang ditimbulkan oleh aset tetap sebagai pengurang penghasilan. Jika aset tetap semakin besar maka laba yang dihasilkan akan semakin kecil karena adanya beban penyusutan yang terdapat dalam aset tetap yang dapat mengurangi 
laba. Perusahaan yang memutuskan untuk berinvestasi dalam bentuk aset tetap dapat menjadikan biaya penyusutan sebagai biaya yang dapat dikurangkan dari penghasilan dan akan menyebabkan laba kena pajak perusahaan menjadi berkurang yang pada akhirnya akan mengurangi jumlah pajak yang harus dibayar perusahaan (Jama, 2018)

Dalam hal ini dinyatakan bahwa intensitas aset tetap berpengaruh terhadap agresivitas pajak. Beban depresiasi timbul karena adanya penyusutan aktiva tetap (Wulansari, Titisari, \& Nurlaela, 2020). Oleh karena itu, perusahaan dengan tingkat intensitas aset tetap yang tinggi yang ada akan menyebabkan semakin turun agresivitas pajak.

Hasil penelitian ini konsisten dengan penelitian yang dilakukan oleh (Savitri \& Rahmawati, 2019) menyatakan bahwa intensitas modal berpengaruh terhadap agresivitas pajak. Hal ini bertolak belakang dengan penelitian yang dilakukan oleh (Adisamartha \& Noviari, 2015) yang menyimpulkan intensitas modal tidak berpengaruh terhadap agresivitas pajak.

\section{Pengaruh Ukuran Perusahaan Terhadap Agresivitas pajak}

Ukuran perusahaan dinilai dari besarnya nilai equity, nilai penjualan atau nilai aktiva sehingga perusahaan dapat dikategorikan. Perusahaan besar memiliki perencanaan pajak yang matang dan mengadopsi praktek akuntansi yang efektif untuk menurunkan ETR perusahaan (Leksono, Albertus, \& Vhalery, 2019). Aset yang dimiliki suatu perusahaan berhubungan dengan besar kecilnya perusahaan, semakin besar perusahaan maka semakin besar total aset yang dimilikinya. Aset akan mengalami penyusutan setiap tahunnya dan juga dapat mengurangi laba bersih perusahaan, sehingga dapat menurunkan beban pajak yang dibayarkan oleh perusahaan.

Dalam hal ini dinyatakan bahwa ukuran perusahaan berpengaruh terhadap agresivitas pajak. Dimana semakin besar perusahaan maka digambarkan dengan total asset perusahaan yang semakin besar pula. Total asset yang dimiliki perusahaan bisa menggambarkan besarnya biayabiaya yang dikeluarkan perusahaan sehingga total asset berpengaruh terhadap agresivitas pajak (Sari \& Rahayu, 2020).

Penjualan yang dilakukan perusahaan akan memengaruhi banyaknya laba perusahaan. Semakin besar laba yang dimiliki suatu perusahaan akan berdampak semakin besarnya juga pajak yang harus dibayarkan perusahaan tersebut. Sejalan dengan teori akuntansi positif, dalam rangka meyakinkan pemerintah bahwa profit yang dimiliki perusahaan tidak terlalu besar perusahaan akan mengadopsi kebijakan akuntansi income-decreasing (pendapatan menurun).

Hasil penelitian ini konsisten dengan penelitian yang dilakukan oleh (Nugraha \& Meiranto, 2015) yang menyimpulkan ukuran perusahaan berpengaruh terhadap agresivitas pajak.

\section{KESIMPULAN}

Dari hasil pengujian hipotesis dalam penelitian ini disimpulkan bahwa : intensitas persediaan tidak berpengaruh terhadap agresivitas pajak, sehingga mendukung dengan teori akuntansi positif. Intensitas modal, Intensitas aset tetap dan ukuran perusahaan berpengaruh terhadap agresivitas pajak, hasil penelitian ini mendukung teori akuntansi positif.

\section{REFERENSI}

Adisamartha, I., \& Noviari, N. (2015). PENGARUH LIKUIDITAS, LEVERAGE, INTENSITAS PERSEDIAAN DAN INTENSITAS ASET TETAP PADA TINGKAT AGRESIVITAS WAJIB PAJAK BADAN. 13(3), 973-1000.

Allo, M. R., Alexander, S. W., \& Suwetja, I. G. (2021). Pengaruh Likuiditas dan Ukuran Perusahaan Terhadap Agresivitas Pajak (Studi Empiris Pada Perusahaan Manufaktur Yang Terdaftar di BEI Tahun 2016-2018. Jurnal EMBA Vol.9 No.1, 647-657.

Amalia, D. (2021). PENGARUH LIKUIDITAS, LEVERAGE DAN INTENSITAS ASET TERHADAP AGRESIVITAS PAJAK. KRISNA: Kumpulan Riset Akuntansi, 12(2), 232240. https://doi.org/10.22225/kr.12.2.1596.232-240

Andhari, P. A. S., \& Sukartha, I. M. (2017). PENGARUH PENGUNGKAPAN CORPORATE SOCIAL RESPONSIBILITY, PROFITABILITAS, INVENTORY INTENSITY, CAPITAL INTENSITY DAN LEVERAGE PADA AGRESIVITAS PAJAK. 28. 
Anindyka, D., Pratomo, D., \& Kurnia. (2018). PENGARUH LEVERAGE (DAR), CAPITAL INTENSITY DAN INVENTORY INTENSITY TERHADAP TAX AVOIDANCE (Studi Pada Perusahaan Makanan dan Minuan di Bursa Efek Indonesia (BEI) Tahun 2011-2015) EFFECT OF LEVERAGE (DAR), CAPITAL INTENSITY AND INVENTORY INTENSITY ON TAX AVOIDANCE (Study On Food and Beverages Companies Listed in Indonesia Stock Exchange Year 2011- 2015). E-Proceeding of Management, 5(1).

Ayem, S., \& Setyadi, A. (2019). Pengaruh Profitabilitas, Ukuran Perusahaan, Komite Audit Dan Capital IntensityTerhadap Agresivitas Pajak (Studi Pada Perusahaan Perbankan Yang Terdaftar di BEI Periode Tahun 2013- 2017). JURNAL AKUNTANSI PAJAK DEWANTARA, 1(2).

Dharma, I. M. S., \& Ardiana, P. A. (2016). PENGARUH LEVERAGE, INTENSITAS ASET TETAP, UKURAN PERUSAHAAN, DAN KONEKSI POLITIK TERHADAP TAX AVOIDANCE. 30.

Efrinal, \& Chandra, A. H. (2020). Pengaruh Capital Intensity dan Inventory Intensity Terhadap Agresivitas Pajak. AKRUAL Jurnal Akuntansi dan Keuangan Vol.2 No.2, 135-148.

Friskianti, Y., \& Handayani, B. D. (2014). PENGARUH SELF ASSESSMENT SYSTEM, KEADILAN, TEKNOLOGI PERPAJAKAN, DAN KETIDAKPERCAYAAN KEPADA PIHAK FISKUS TERHADAP TINDAKAN TAX EVASION. 10.

Hanum, H. R. (2013). PENGARUH KARAKTERISTIK CORPORATE GOVERNANCE TERHADAP EFFECTIVE TAX RATE. 10.

Indradi, D. (2018). PENGARUH LIKUIDITAS, CAPITAL INTENSITY TERHADAP AGRESIVITAS PAJAK ( Studi empiris perusahanManufaktur sub sektor industri dasar dan kimia yang terdaftar di BEI tahun 2012-2016.). Jurnal Akuntansi Berkelanjutan Indonesia, l(1).

invesnesia.com. (n.d.). Retrieved September 17, 2021, from https://www.invesnesia.com/perusahaan-makanan-dan-minuman-di-bei

Ghozali, I. (2016). Aplikasi Analisis Multivariete dengan Program IBM SPSS 23 (edisi 8) Cetakan ke VIII. Semarang: Badan Penerbit Universitas.

Karisma Adiputri, D. P., \& Erlinawati, N. A. (2021). Pengaruh Profitabilitas, Likuiditas dan Capital Intensity Terhadap Agresivitas Pajak. Hita Akuntansi dan Keuangan Universitas Hindu Indonesia, 467-487.

Kuriah, H. L., \& Asyik, N. F. (2016). PENGARUH KARAKTERISTIK PERUSAHAAN DAN CORPORATE SOCIAL RESPONSIBILITY TERHADAP AGRESIVITAS PAJAK. 5, 19.

Leksono, A. W., Albertus, S. S., \& Vhalery, R. (2019). Pengaruh Ukuran Perusahaan dan Profitabilitas terhadap Agresivitas Pajak pada Perusahaan Manufaktur yang Listing di BEI Periode Tahun 2013-2017. JABE (Journal of Applied Business and Economic), 5(4), 301. https://doi.org/10.30998/jabe.v5i4.4174.

Lestari, P., Pratomo, D., \& Asalam, A. (2019). Pengaruh Koneksi Politik dan Capital Intensity Terhadap Agresivitas Pajak. Jurnal ASET (Akuntansi Riset), 11(1).

Mardiasmo. (2016). Dalam Perpajakan. Yogyakarta, Universitas Gajah Mada.

Maulidah, H., \& Prastiwi, D. (2019). PENGARUH CORPORATE SOCIAL RESPONSIBILITY, INTENSITAS MODAL, DAN PERSAINGAN TERHADAP AGRESIVITAS PAJAK PERUSAHAAN. AKUNESA: Jurnal Akuntansi Unesa, 8(1).

Ngadiman, N., \& Puspitasari, C. (2017). PENGARUH LEVERAGE, KEPEMILIKAN INSTITUSIONAL, DAN UKURAN PERUSAHAAN TERHADAP PENGHINDARAN PAJAK (TAX AVOIDANCE) PADA PERUSAHAAN SEKTOR MANUFAKTUR YANG TERDAFTAR DI BURSA EFEK INDONESIA 2010-2012. Jurnal Akuntansi, 18(3). https://doi.org/10.24912/ja.v18i3.273.

Novitasari, S. (2017). PENGARUH MANAJEMEN LABA, CORPORATE GOVERNANCE, DAN INTENSITAS MODAL TERHADAP AGRESIVITAS PAJAK PERUSAHAAN (Studi Empiris pada Perusahaan Property dan Real Estate yang Terdaftar di BEI Periode Tahun 2010-2014). JOM Fekon, 4(1). 
Priscilla Putri, K. K., Febrina, R., Veravashti, Y. V., \& Effriyanti, E. (2020). Pengaruh Likuiditas dan Leverage Terhadap Agresivitas Pajak. Prosding PIM Vol.1 No 2.

Rahayu, P. (2017). PENGARUH UKURAN PERUSAHAAN, LAVERAGE, PROFITABILITAS, MARKET TO BOOK RATIO, KEPEMIIKAN MAYORITAS DAN CORPORATE SOCIAL RESPONSIBILITY TERHADAP AGRESIVITAS PAJAK. Accounting Global Journal, 1(1). https://doi.org/10.24176/agj.v1i1.3326.

Resmi, S. (2017). Perpajakan teori \& kasus. Salemba Empat. Jakarta.

Susanti, D., \& Satyawan, M. D. (2020). Pengaruh Advertising Intensity, Inventory Intensity dan Sales Growth Terhadap Agrevisitas Pajak. AKUNESA: Jurnal Akuntansi Unesa Vol.9 No.1.

Suyanto, K. D. (2012). LIKUIDITAS, LEVERAGE, KOMISARIS INDEPENDEN, DAN MANAJEMEN LABA TERHADAP AGRESIVITAS PAJAK PERUSAHAAN. 16, 11.

Wardhani, R. A., \& Muid, D. (2017). PENGARUH AGRESIVITAS PAJAK, UKURAN PERUSAHAAN DAN UKURAN PERUSAHAAN DAN PROFITABILITAS TERHADAP CORPORATE SOCIAL RESPONSIBILITY. 10. 